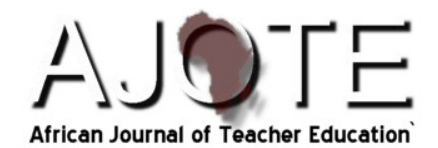

ISSN: 1916-7822 A Journal of Spread Corporation

Volume 1 No. $1 *$ Pages 222-229 * October 2010

\title{
THE RELEVANCE OF SCIENCE, TECHNOLOGY AND MATHEMATICS EDUCATION (STME) IN DEVELOPING SKILLS FOR SELF RELIANCE: THE NIGERIAN EXPERIENCE
}

\author{
Suleiman Sa'adu Matazu \\ Usmanu Danfodiyo University, Sokoto-Nigeria. \\ Justmatazu@yahoo.com,ssmatazu@yahoo.com.
}

Science, Technology and Mathematics Education (STME) has been proved to be an indispensable factor in the economic development of any country; and for Nigeria, it has a more critical role to play. This paper examines the relevance of science, technology and mathematics education (STME) for national development and self-reliance of Nigerian citizens. A historical overview of the interconnectivity of science, technology and mathematics education (STME) and self reliance is highlighted. The current situation and challenges facing STME in Nigeria are also highlighted to bring out the theoretical relevance of (STME) for self reliance which actually has not been practically realized. The author's recommendations include the call for training and re-training of STME teachers to update their knowledge, and the provision of long vocation/weekend programmes for out of school individuals, among others. 


\section{The Relevance of Science, Technology and Mathematics Education (STME) in Developing Skills for Self Reliance: the Nigerian Experience}

\section{INTRODUCTION}

Relevance simply means to be directly connected with the subject being discussed or considered. This implies that, the paper attempts to bring out the direct connection between Science, Technology and Mathematics Education (STME) for self-reliance. Although Nigeria is rich in human and natural resources, it is still one of the poorest and underdeveloped countries of the world. The climax is that there are so many graduates of the nation's education system who are roaming about the streets as unemployed and job-seekers (Nwachukwu, 2009). This situation is contrary to the aims and objectives of Nigerian education stipulated in the National policy on Education (FRN 2004), which stresses the development of a self-reliant nation. This shows that the policies and the practices in the schools have some yawning gaps (Offorma, 2005). In reality, products from good STM education ought to have acquired sufficient skills that would make them self reliant, prepare them to enter into jobs and make progress in them. STME should prepare individuals to be self employed in various enterprises.

The delivery of Science, Technology and Mathematics Education should be practical oriented, but it is theorized because of lack of competent teachers or lack of equipment to enable that. Hence, students graduate without any hands-on skills, and minds-on experience (Offorma, 2005). This trend tends to obscure the relevance of STM education in the development of skills necessary for self reliance. Such constructs as, curiosity, open mindedness, creativity, aptitude among others, which are often used in connection with science, technology and mathematics education are also relevant and applicable for the development of skills for self reliance.

It is against this background that this paper examines the relevance of Science Technology and Mathematics Education for effectively developing skills for self reliance in Nigeria.

\section{Theoretical Framework}

Science, Technology and Mathematics Education (STME) have been called a meta discipline, the creation of a discipline based on the integration of other disciplinary knowledge into a new whole. This interdisciplinary knowledge bridging among discrete disciplines is now treated as an entity known as STM Education (Morrison, 2006). Thus, STM Education offers students one of the best opportunities to make sense of the world holistically, rather than in bits and pieces.

It should be noted, however, that STM Education is an interdisciplinary approach to learning; where rigorous academic concepts are coupled with real world lessons as students apply STM in the context that make connections between schools, community, work and the global enterprises enabling the development of STM literacy and self reliance skills, and with it, the ability to compete in the new economy (Tsupros et al, 2009).

\section{Historical Overview}

Science and Technology have been instrumental in shaping and improving the life of mankind. While science tries to explain things, technology is what has enabled mankind to 
improve his standard of living, not only to build houses, supply food, health, travel and communications but arts, sculpture, music and literature (Mutasa in Nwachuku, 2009). Thus, the purpose of technology is the application of human knowledge for the betterment of human life. Hence, technology, therefore, seems to be a cultural activity and every society is technological and scientific in varying degrees and mathematics is the vehicle for doing science and a tool for technologies (Wasagu, 2009).

Past researchers revealed that Africans developed Arithmetic, Algebra, Geometry, trigonometry and other advanced mathematical science (Diop, 1974). They employed these concepts in the construction of pyramid, mathematical calculations relating to the flooding of Nile, and in the division of land along the Nile valley. The Egyptians also possessed considerable knowledge of chemistry, and the use of metallic oxides is evident from the nature of colors applied to their glass and porcelain. They were even acquainted with the influence of acids upon color. Hence, they were able in the process of dyeing/staining cloth, to bring out certain changes in the hues by the same method adopted in our own cotton works (Sweeting and Edmond, 1989).

Amongst a host of technological inventions were tools-copper and iron and latter steel, boat and ship design. The sale of sails was one of Egypt's industries. Also, there existed the art of shaving, use of wigs, wearing of kilts and sandals, musical instruments, chairs, beds, cushions and jewelry. There was smelting of iron for producing good quality carbon steel. With this enterprise, they were self employed and become self reliant. Analysts have argued tremendous improvement recorded in science and technology over the years have been met with a corresponding decrease in the technological skills possessed by individuals and their communities which make them self reliant. This could be witnessed in many developed societies where the science and technological discoveries and inventions have been applied in different human development fields for national development.

In our national context, several strides have been made by many people in the rural and urban Nigerian where skilled men had produced the needed farming implements, local guns for hunting animals in the forests, machetes and hoes for clearing the land for agricultural activities, and many other locally-made tools that would earn them a living; women were able to brew local beverages and wine, weave and dye cloths, utilize clay materials for earthenware bowls, pots, among others. Nowadays, it is difficult to find individuals with such self reliant skills in the community (Nwachukwu, 2009) due to the non-commitment of the system to the development of local human potentials and resources in the environment. This means, technology now belongs to large corporations and people have increasingly become jobless, job seekers and indeed marginalized in the industrial development, production and employment sector. Thus, if the interconnectivity of these different disciplines science, technology and mathematics education are wisely utilized, it is of great advantage for the development of necessary skills for selfreliance.

\section{Current Situation of STM Education in Nigeria}

Oriafo (2002) argued that science, technology and mathematics education in Nigeria are grossly characterized by inadequacy of content and ineffective methodology by teachers, paucity of facilities, equipment and materials in our laboratories, as well as dominated socio-cultural lapses. These lapses have to be properly tackled for our STM education to produce individuals with sufficient skills capable for self-reliant life activities.

The present trend of mass unemployment in Nigeria shows that the STM being taught in schools do not prepare Nigerian graduates to function well in the nation undergoing transition

AJOTE Vol. 1. No. 1, 222-228 
from rural economy to modern economy (Nwachukwu, 2009). The courses which should be taught as hands-on and minds-on practical courses are basically taught theoretically; this makes the learners not to benefit maximally from their education. Hence, development of useful skills necessary for self reliant living is lacking.

\section{Self Reliance as it relates to STM Education}

One of the main objectives of National Policy on Education (NPE) is the "Acquisition of appropriate skills for self-reliant nation". Self-reliance is an expression which has become conceptually and practically attractive, particularly in developing countries, wrestling with the economic forces of meeting numerous needs with limited resources (Jimo, 2009). Even though there is no nation that is completely self sufficient, but the craze to bring out the best that is possible in a nation's human and materials endowments informs self reliance.

Self-reliance is one of those euphemistic terms bandied about, like bridging the gap; meeting basic needs; and eco-development in the international effort to reduce hunger, disease, unemployment and general poverty. With the apparent failure of regional and international governments, multinational corporations and even humanitarian organizations to achieve these goals, there is a resort to an inward looking tendency of self-help as a way out, after all, selfreliance as a form of social behavior has existed throughout phases of human development (Oxfam, 2002).

Jimo (2009) opined that STM education should prepare individuals for self-reliance. This can be achieved by delivering STM education practically in such away that it enables individuals acquire necessary and vital skills for self employment. It should be noted, however, that alleviating poverty and resuscitating self-reliance which is a prelude to self sufficiency and employment generation can best be achieve in Nigeria when STM Education is taught as handson and minds-on practical activities in our public schools.

\section{Challenges facing STM Education in Nigeria that affect its Expected Outcomes}

Nwachuku (2009) enumerated some of the problems confronting STM education in Nigeria to include, lack of funds to purchase equipment/materials, lack of adequate textbooks, overcrowded classrooms/laboratories, poor time table, lack of cooperation from administrator, the pressure of external certificate examinations, etc. Other challenges, include, lack of proper monitoring and feedback mechanisms, poor preparations of teachers who teach the new programs, lack of motivation among teachers, the rapid rate in which teachers are transferred from one school to another or out of the profession, the use of archaic/traditional teaching methods which ultimately hinders internalization of learned materials

Other problems facing STM Education in Nigeria includes the absence of efforts to bring about meaningful self-reliance programs and projects to the communities. There are lack of planning in different sectors of Nigerian economy; including, poor policy implementation procedures, shortage of qualified STM teachers/educators, over whelming number of activities demanded by the new curricula, lack of clear-cut goals, scarcity of resources and non-usage of research reports on the performance of the programs (evaluation). These are clear challenges facing Nigeria STM Education, and unless these challenges are tackled, the dying relevance of STM Education skills for self-reliance in Nigeria can not be resuscitated. 


\section{The Teacher and the Curriculum}

The meaningful implementation and success of any STME curriculum for self reliance rests heavily on the availability of sufficient number and right caliber of teachers. (Wasagu, 2009). Nigeria has great human resource potentials for all sectors, and many of them could be encouraged to embrace education/the teaching field, trained, and equipped with practical skills and resource materials that would facilitate youth development training in various communities. Such are positive ways to begin imparting the spirit of self reliance and nationalism among the citizens.

Furthermore, since the teacher is the translator, interpreter and trusted executor of the school curriculum in the classroom, then Nigerian STME teachers are the central figures in the meaningful realization of the program, as enshrined in the public school curriculum. The actualization of the goals and benefits of STM Education for self-reliance is a heavy task, highly demanding on the teacher (the implementer) and the school system. This is because, the teacher as the implementer of the curriculum, mediates between the curriculum aims and objectives, contents and materials, and the learner (Nwachukwu, 2009). The teacher is responsible for selecting the content, materials, strategies and pedagogies, preparation and presentation of the content to learners, evaluation and feedback. In addition, the teacher is faced with the task of constantly motivating and reinforcing the learners, as well as provision of suitable socioemotional atmosphere that is conducive for learning in order to achieve the desired goals (Nwachukwu, 2009).

For effective and efficient execution of these laudable tasks by the teacher, Morrison (2006) advised that the teacher be properly trained, and must acquire a mastery of vast arrays of skills and competences. Examples of such skills are knowledge of the subject content, practical competence, minds-on and hands-on, pedagogical competencies, etc. Furthermore, teachers should view the learners as beginners; hence, they need to adopt practical approaches, such as, use of concrete examples and improvisations. Since the acquisition of skills necessary for selfreliance are all embracing, practical activities should be extended to simulations, games, etc. Since no educational system or curriculum could rise above the quality of its teachers, it is pertinent that teachers should be trained with variety of pedagogical approaches which will facilitate acquisition of skills needed for self employment and the corresponding effect would be self reliance.

\section{Recommendations}

Based on the discussions in this paper, the following recommendations are made;

a) STME teachers should be properly trained, provided with adequate knowledge on the subject content, various creative skills, pedagogies and practical approaches of teaching and learning STM Education. This will enhance effective and efficient STM Education capable of producing individuals that are ready for self-reliance.

b) Serving STME teachers also should be retrained, through in-service, workshops, seminars, conferences, and study tours. This will enable them acquire reasonable knowledge capable of producing individuals with enough self reliance skills.

c) Children and young individuals should be given proper value and attitudinal orientation by parents and adults. They should be encouraged to be versatile as white collar jobs are no longer plenty where available. 
d) Long vocation/weekend programmes can be organized for out-of-school individuals, this will help in equipping them with skills they need for self-reliance.

e) There is need for shift of emphasis from certificate acquisition to the acquisition of practical skills and attitude needed for self-reliant life.

f) Government should be ready to invest heavily in STM Education. Good salaries/allowances should be paid to STM teachers, all the necessary materials/equipments and infrastructure needed should be made available, conducive atmosphere for teaching and learning should be provided. With this, the corresponding effect would be performance according to expectations. Nigerian graduates would be properly equipped with all the necessary skills they need for self-reliant life. Hence, the dilemma of seeing uncountable number of unemployed graduates roaming on the street seeking for jobs will drastically reduce.

\section{Conclusion}

This paper has stressed that in the past, acquisition of skills for self-reliance was the target of STM Education. It now shows that a well-planned and implemented science, technology and mathematics education today would play a great role in the development of vital skills to individuals that will enable them to be self employed, self-reliant, hence the ugly situation of massive unemployment of graduate is tackled. 


\section{REFERENCES}

Diop, C.A. (1974). "The African origin of civilization". New York Lawrence Hill and Company. Federal Republic of Nigeria (2004) National policy on education. NERDC Lagos.

Jimbo, B.O (2009). Self Reliance as an impetus for Eradicating poverty in Nigeria. Journal of Humanities, Science and Technology; Niger State Polytechnic Zungeru. 124-130.

Morrison, J. (2006). Ties STM Education Monograph Series: Attributes of science, technology and mathematics education. Wadsworth Publishing Company Belmont. U.K.

Nwachukwu, C. (2009). The relevance of the science, technology and mathematics education $(S T M E)$ to development of entrepreneurial skills. Proceedings of the $50^{\text {th }}$ Annual Conferences of Science Teacher Association of Nigeria 312-324.

Offorma, G.C (2005). Curriculum for wealth Creation. Paper Presented at the Seminar of the World Council for Curriculum and instruction held at Kano, Oct, 25.

Oriafo, S.O. (2002). Refocusing science, technology and mathematics (STM) education in Nigeria: A book of Readings. Agbor: Kmensuo Educational Publishers.

Oxfam, K.W (2002). The global gap between the rich and the poor is getting wider. London: The Brookings institution.

Sweeting, E and Edmond, L. (1989). "African history: An illustrated handbook". Islington Council, London.

Tsupros, N.R., Hallinen, J. (2009). STM education: A project to identify the missing icon. Kmensuo Educational Publishers.

Wasagu, M.A. (2009). Rethinking Science Education for changing Times: The writing on the wall. Eight inaugural lecture of Usmanu Danfodiyo University Sokoto. March 26. 